\title{
HEALTH RISK MANAGEMENT IN OCCUPATIONAL MEDICINE
}

UDC 614.2: 613.62

DOI: $10.21668 /$ health.risk/2017.4.09.eng

\section{CONTEMPORARY PROBLEMS OF HEALTH PROTECTION FOR WORKERS EMPLOYED AT A LARGE INDUSTRIAL ENTERPRISE AND WORKING UNDER OCCUPATIONAL HAZARDS}

\section{E.Ya. Titova, S.A. Golub'}

Perm State Medical University named after Academician E.A. Wagner, 26 Petropavlovskaya Str., Perm, 614000, Russian Federation

We examined data provided by a healthcare facility at a large industrial enterprise focusing on occupational morbidity dynamics over 2013-2016 and periodical medical examinations results obtained in 2015 and 2016. We created a specialized program and applied it to conduct sociological research on health of workers who has a periodical medical examination. We detected that most questioned workers (50.48\%) whose occupations were associated with dangerous and hazardous occupational factors were poorly aware of occupational diseases prevention and needed relevant knowledge. It is shown that over 2013-2016 occupational morbidity decreased from 9.38 cases per 10,000 workers to 3.55 cases. However, it remained higher that in Russian and Perm region on average.

All occupational diseases were detected in workers older than 40 with their working record being longer than 15 years. A share of people able to work with certain limitations grew in 2016 in comparison with 2015 (from 7.35 to $9.31 \%$ ); a number of people who needed sanatorium-resort therapy also grew from 19.96 to $32.12 \%$; a number of people with general somatic diseases increased from 31.23 to $70.17 \%$ ); health index reduced from 38.77 to $29.82 \%$. Musculoskeletal system diseases, connective tissue diseases, circulatory system diseases, eye and its accessory apparatus diseases, respiratory organs diseases, and digestive organs diseases prevailed in general somatic morbidity structure. We registered a substantial growth in hearing organs diseases (mostly hearing loss, from 49.47 to 99.06 cases per 100 examined); skin and subcutaneous tissue diseases (from 7.73 to 36.3 cases per 100 examined); urinary system diseases (from 68.42 to 100.62 cases per 100 examined). We detected that most examined workers pursued unhealthy lifestyle. For example, $29.9 \%$ often consumed strong spirits (equally men and women), and $72.8 \%$ smoked. All the respondents tended to have low physical activity. We also revealed some drawbacks in periodical medical examinations procedure: $26.3 \%$ respondents mentioned medical staff were indifferent and even rude to them; $40.8 \%$ complained on having to wait for a long time to get to a specialist; $26.2 \%$ said they had to wait for a reception in rather unfavorable conditions; all the respondents mentioned untimely receipt of their "health passport".

The data we collected can be applied in assessing risks of health disorders occurrence in workers employed at industrial enterprises and in the process of creating prevention activities aimed at health risks minimization.

Key words: large industrial enterprise, occupational morbidity, periodical medical examination, morbidity, morbidity structure, workers' lifestyle, working conditions, medical examinations drawbacks.

A most important social and economic Strategy" which was approved by the RF task fixed in "The RF National security President Order No. $683^{1}$ dated December

(C) Titova E.Ya., Golub' S.A., 2017

Elena Ya. Titova - Associate Professor at Public Health and Healthcare Department, Candidate of Medical Sciences (e-mail: superoziz@yandex.ru; tel: +7 (342) 233-25-31).

Svetlana A. Golub' - Student (e-mail: superoziz@yandex.ru; tel: +7 (342) 233-25-31). 
$31 / 2015$ is to preserve and to improve working population health. Today, as our society is undergoing reforms in many spheres, safe working conditions in industry and workers' health protection are among factors securing economic development of our country [4,5,12-15]. All workers exposed to industrial hazardous factors existing at their workplaces run risks of occupationally-induced pathology evolvement [11].

Occupational risk concept was adopted in Russia and it became a significant stage in labor protection system improvement as it allowed to make activities aimed at workers' health preservation and improvement more prevention-oriented which was especially important for those workers who had to perform their tasks under hazardous conditions [3]. Safe working conditions and low risks of impacts exerted by unfavorable environmental factors on working population are the most important conditions for persistent social and economic development of any state. Prevention of health disorders in workers, first of all, occupational and occupationally induced ones, is among priority tasks occupational medicine has to solve [5].

Personnel health management is seen as a most important technique in economically developed countries; when we apply it, we can cut organizational costs due to decrease in morbidity and labor productivity growth. Countries which are able to do it are the most competitive [16, 17].

The RF Government issued the Order No. 2580-r on December 28, 2012 approving "Medical Science Development
Strategy in the RF up to $2025^{\prime 2}$; this strategy stresses the necessity to "change priorities in planning strategies aimed at population health improvement, namely, to make emphasis not on clinical approaches but on prevention programs". A priority task is to develop a set of activities which can help to prevent hazardous impacts exerted by working conditions on health. "Global Plan of Action on Workers' Health" was approved on the 60th WHO session (May 23, 2007); it contains the following: "workers' health is determined both by risk factors existing at a workplace and by social and individual factors, as well as by a free access to medical and sanitary service" [2].

As per data taken from official statistics contained in Rospotrebnadzor state reports, occupational morbidity in the RF still remains high despite a slight decrease which was detected in the parameter in 2016 against 2015, being equal to 1.47 cases per 10,000 workers (it was 1.76 cases in 2013; in 2014, 1.74 cases; in 2015, 1.65 случаев) [8-10]. Occupational morbidity in Perm region annually is higher than the average country level: 1.83 cases in 2013; 1.86 , in $2014 ; 1.37$, in $2015 ; 1.2$ cases per 10,000 workers in 2016 [6,7].

Our research goal was to examine certain contemporary problems related to health protection of workers employed at a large industrial enterprise.

Data and methods. We studied data on occupational morbidity taken from reports collected in 2013-2016 by a health station at a large industrial enterprise and

\footnotetext{
${ }^{1}$ On the Russian Federation National Security Strategy: The RF President Order dated December 31,2015 No. 683. ConsultantPlus. Available at: http://www.consultant.ru/document/cons_doc_LAW_191669/ (10.08. 2017)

${ }^{2}$ Medical Science Development Strategy in the RF up to 2025 / approved by the RF Government Order on December 28, 2012 No. 2580-r. Available at: https://www.rosminzdrav.ru/documents/5413-rasporyazheniepravitelstva-rossiyskoy-federatsii-ot-28-dekabrya-2012-g-n-2580-r (10.08. 2017)
} 
compared them with average country parameters and Perm region parameters. We also compared results of workers' medical examinations performed in 2015 and 2016. We found out how aware workers were on occupational hazards and occupational diseases prevention; to do that, we applied a specially designed sociological research program which also allowed us to analyze respondents' lifestyle and to examine their opinions on periodical medical examinations. We calculated relative and average values, assessed their validity, and determined dynamic series parameters (average chronological value and growth rate). When assessing validity of discrepancies in relative and average values, we applied Student's t-criterion.

Our research was performed at a large industrial enterprise; about 3,000 workers were employed at it. Basic hazard occupational factors there were noise, chemicals, labor hardness, increased air temperature, vibration, and ionizing radiation. According to the Order issued by the RF Labor Ministry on January 24, 2014 No. 33n "On approving a specialized working conditions assessment procedure" ${ }^{3}$, most working places at an enterprise correspond to 3.3 or 3.4 danger category as per working conditions existing at them.

Results and discussion. Our research revealed that 5,000 occupational diseases were registered at the examined enterprise in 2013-2016. Average working period for workers with a diagnosed occupational diseases was equal to $16.2 \pm 0.9$ years, their average age was $43.8 \pm 1.1$. In 20161 occupational disease case, namely chronic toxic bronchitis, was detected, just like in 2015.
Primary occupational morbidity frequency dropped by $62.15 \%$ in 2016 in comparison with 2013 and amounted to 3.55 cases per 10,000 workers. Average chronic diseases values in 2013-2016 amounted to $1.66 \pm 0.14$ cases per 10,000 workers in Russia; $1.57 \pm 0.16$ cases per 10,000 workers in Perm region; $4.14 \pm 1.95$ cases per 10,000 workers at the examined enterprise (Figure 1).

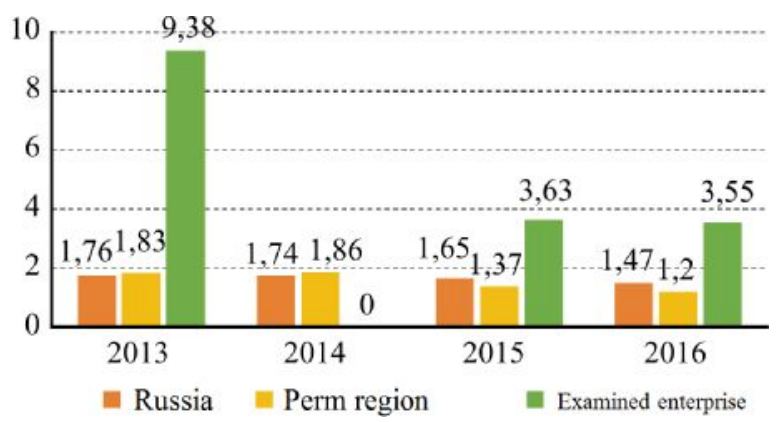

Figure 1. Occupational morbidity dynamics for workers employed at the examined enterprise, in Perm region, and in Russia (per 10,000 workers).

Table 1

Results of workers' periodical medical examinations

\begin{tabular}{|l|c|c|}
\hline \multicolumn{1}{|c|}{ Parameters } & 2015 & 2016 \\
\hline $\begin{array}{l}\text { A share of those who attended } \\
\text { PME from the overall number of } \\
\text { workers who had to attend it, \% }\end{array}$ & 99,30 & 99,10 \\
\hline $\begin{array}{l}\text { A share of people who needed ad- } \\
\text { ditional examinations (health report } \\
\text { not given) \% }\end{array}$ & 7,35 & 9,31 \\
\hline $\begin{array}{l}\text { A share of workers fit for work } \\
\text { with certain limitations, \% }\end{array}$ & 4,20 & 5,18 \\
\hline $\begin{array}{l}\text { A share of workers without any } \\
\text { medical contraindications for } \\
\text { work, \% }\end{array}$ & 88,51 & 84,75 \\
\hline $\begin{array}{l}\text { A share of workers who needed } \\
\text { sanatorium-resort treatment, \% }\end{array}$ & 19,96 & 32,12 \\
\hline $\begin{array}{l}\text { A share of workers with general } \\
\text { somatic diseases, \% }\end{array}$ & 61,23 & 70,17 \\
\hline "Health index", \% & 38,77 & 29,82 \\
\hline
\end{tabular}

\footnotetext{
${ }^{3}$ On approving a specialized working conditions assessment, Classifier of hazardous and (or) dangerous occupational factors, a reporting form for specialized working conditions assessment and an instruction on how to fill it in correctly": The Order by the RF Labor Ministry issued on January 24, 2014 No. 33n (edited on November 14, 2016). ConsultantPlus. Available at: http://www.consultant.ru/document/cons_doc_LAW_158398/ (08.08.2017).
} 
Analysis of periodical medical examinations (PME) results revealed that parameters deteriorated in 2016 in comparison with 2015 (Table 1):

- a share of workers without any medical contraindications for work decreased from $88.51 \%$ to $84.75 \%$, and a share of those fit for work only with limitations increased from $4.2 \%$ to $5.18 \%$;

- a share of workers who needed additional examinations increased from $7.35 \%$ to $9.31 \%$; and a share of those who needed sanatorium-resort treatment, from $19.96 \%$ to $32.12 \%$;

- a share of worker who had general somatic diseases grew from $61.23 \%$ to $70.17 \%$;

- health index fell from $38.77 \%$ to $29.82 \%$.

As per medical examinations data, morbidity frequency grew from $1,178.58$ cases to $1,564.3$ cases per 100 examined workers in 2016 (by $32.73 \%$, the difference is statistically authentic, $\mathrm{p} \leq 0.05)$. Morbidity grew practically as per each nosologic category: skin and subcutaneous tissue diseases grew by $369.6 \%$; ear and mastoid diseases, by $100.24 \%$; blood and blood making organs diseases, by $48.43 \%$; musculoskeletal system diseases, by $41.71 \%$; eye and its accessory apparatus diseases, by $34.68 \%$; neoplasms, by $33.33 \%$; circulatory system diseases, by $31.65 \%$; endocrine system diseases, nutrition disorders and metabolism disorders, by 5.84\% (Figure 2).

The same 5 nosologies prevailed in morbidity structure in 2015, as it was in 2015. Their share was equal to $77.37 \%$ in 2016 and to $73.98 \%$ in 2015. However, their ranking changed a bit.

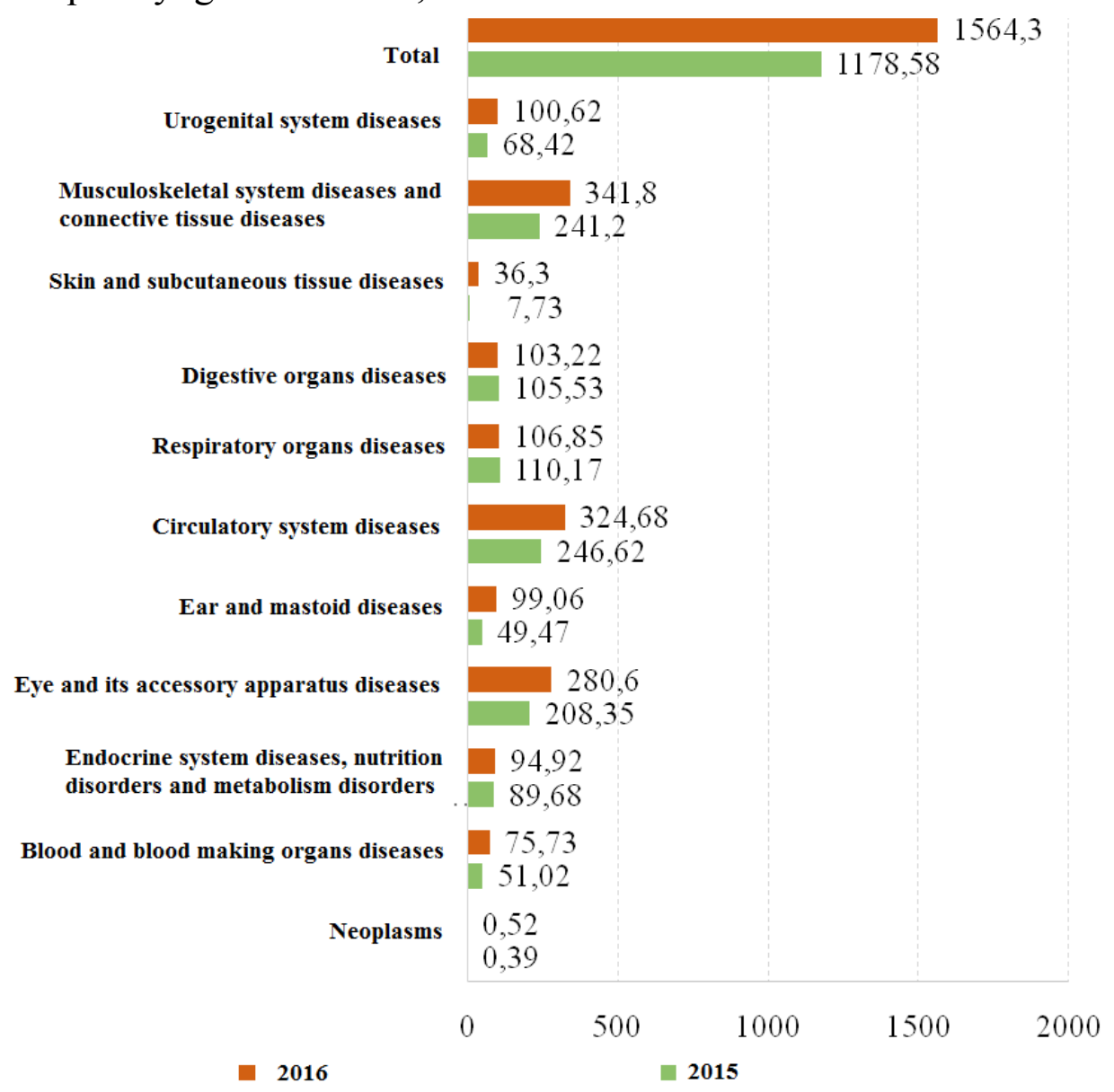

Figure 2. Morbidity frequency as per medical examinations data (per 100 examined) 
Thus, musculoskeletal system diseases and connective tissue diseases took the first place in $2016(21.85 \%)$, but this place belonged to circulatory system diseases in 2015 (20.92\%). Circulatory system diseases took the second place in $2016(20.76 \%)$, but in 2015 it belonged to musculoskeletal system diseases and connective tissue diseases $(20.47 \%)$. Eye and its accessory apparatus diseases held the third place both in 2016 and 2015 (17.94\% and 17.68\% correspondingly). The fourth place belonged to respiratory organs diseases $(6.83 \%$ and 9.35\% correspondingly). Digestive organs diseases took the fifth place both in 2015 and $2016(6.6 \%$ and $8.95 \%$ correspondingly) (Table 2).

Table 2

Morbidity structure as per medical examinations data in 2015 and $2016(\%)$

\begin{tabular}{|l|c|c|}
\hline \multicolumn{1}{|c|}{ Parameter } & 2015 & 2016 \\
\hline Neoplasms & 0,03 & 0,03 \\
\hline $\begin{array}{l}\text { Blood and blood making organs } \\
\text { diseases }\end{array}$ & 4,33 & 4,84 \\
\hline $\begin{array}{l}\text { Endocrine system diseases, nutri- } \\
\text { tion disorders and metabolism dis- } \\
\text { orders }\end{array}$ & 7,61 & 6,07 \\
\hline $\begin{array}{l}\text { Eye and its accessory apparatus dis- } \\
\text { eases }\end{array}$ & 17,68 & 17,94 \\
\hline $\begin{array}{l}\text { Ear and mastoid diseases (including } \\
\text { hearing loss) }\end{array}$ & 4,20 & 6,33 \\
\hline Circulatory system diseases & 20,92 & 20,76 \\
\hline Respiratory organs diseases & 9,35 & 6,83 \\
\hline Digestive organs diseases & 8,95 & 6,60 \\
\hline $\begin{array}{l}\text { Skin and subcutaneous tissue dis- } \\
\text { eases }\end{array}$ & 0,66 & 2,32 \\
\hline $\begin{array}{l}\text { Musculoskeletal system and con- } \\
\text { nective tissue diseases }\end{array}$ & 20,47 & 21,85 \\
\hline Urogenital system diseases & 5,81 & 6,43 \\
\hline Total morbidity & $\mathbf{1 0 0 , 0 0}$ & $\mathbf{1 0 0 , 0 0}$ \\
\hline
\end{tabular}

Sociological research performed on workers who attended a medical examination revealed that most respondents were $30-49$ years old $(46.6 \%)$ and $50-59$ years old (38.8\%); only $6.8 \%$ were 60 and older. Most respondents worked at the examined enterprise for a long time: $35.9 \%$ for 11 years and longer; $30.1 \%$, 6-10 years; $23,3 \%$, 4-5 years; only $1.0 \%$ respondents worked there less than 1 year. $87.3 \%$ respondents had secondary vocational education, $6.8 \%$ had higher education. $41.7 \%$ respondents were females, and $58.3 \%$ males.

We detected that $50.5 \%$ were poorly aware of hazardous occupational factors existing at their enterprise and of their influence on workers' health as well as of occupational diseases prevention; but they were eager to get this knowledge.

Nicotine addiction prevailed among workers as $72.8 \%$ of them smoked: $85.0 \%$ men and $56.0 \%$ women. Smoking prevalence among workers employed at various industrial enterprises in Perm region was also detected by other researchers [5]; they give data on a share of smoking workers varying from 56 to $78 \%$. And here there are no authentic discrepancies between men and women $(p \geq 0.05)$. We detected that $29.9 \%$ respondents drank strong spirits several times a month and even more often (discrepancies in alcohol intake between men and women are also statistically insignificant, $\mathrm{p} \geq 0.05$ ). These results are well in line with data obtained at other regional industrial enterprises [1]. And we should note here that, in spite of rather high prevalence of bad habits among workers, only half of respondents try to abandon them. All the respondents $(100 \%)$ told they had very little physical activity. All the above-mentioned exerts negative influence on workers' health.

Most respondents gave positive assessment of medical personnel work during medical examinations (73.79\%); however, $25.24 \%$ complained on indifferent attitudes towards a patient, and $0.97 \%$ told medical personnel were even rude to them. Time spent in waiting for a doctor's reception was mostly from 10 to 30 minutes as 
$59.22 \%$ mentioned exactly this waiting period; $34.954 \%$ said they had to wait for 31 60 minutes; $5.83 \%$ waited for more than 1 hour. $26.2 \%$ respondents complained on bad conditions in which they had to wait for a doctor's reception.

Besides, respondents were offered to assess certain criteria as per 5-score scale; these criteria characterized a medical examination quality (Table 3 ).

\section{Table 3}

Medical examinations quality assessment as per 5-score scale

\begin{tabular}{|l|c|}
\hline \multicolumn{1}{|c|}{ Criterion } & Average score \\
\hline $\begin{array}{l}\text { The main purpose of a medical exam- } \\
\text { ination is achieved - occupational } \\
\text { and chronic diseases prevention }\end{array}$ & 4,12 \\
\hline $\begin{array}{l}\text { Medical recommendations are given } \\
\text { after an examination }\end{array}$ & 4,15 \\
\hline $\begin{array}{l}\text { "Health report" is received on time } \\
\text { (during 30 days) }\end{array}$ & 2,4 \\
\hline
\end{tabular}

Rather low scores given to a timely receipt of a health report can be explained by a situation when workers have their tests and EEG taken exactly on a day when a medical examination takes place. As there are a lot of workers who have to attend it, research results are often received with a delay.

\section{Conclusions:}

1. Workers employed at the examined enterprise are influenced by dangerous and adverse occupational factors and it exerts negative impacts on their health. Most workplaces belong to 3.3 or 3.4 danger category. But most questioned workers $(50.48 \%)$ are poorly aware of occupational diseases prevention and need this knowledge.

2. In 2013-2016 a decrease in occupational morbidity was observed (from 9.38 to 3.55 per 10,000 workers); however, it still remains significantly higher than in the country or Perm region on average. All the detected occupational diseases during the examined period occurred in workers who worked for more than 15 years at the examined enterprise and was older than 40 .

3. As per medical examinations results obtained in 2016, we detected that a share of workers who were fit for work with certain limitations grew in comparison with 2015 (from 7.35\% to 9.31\%); a share of workers who needed sanatoriumresort treatment also grew (from 19.96\% to $32.12 \%$ ); a share of workers with general somatic diseases grew from $61.23 \%$ to $70.1 \%$ ); overall health index fell from $38.77 \%$ to $29.82 \%$ ).

4. As per medical examinations data, the same nosologic forms prevailed in the overall morbidity structure both in 2015 and 2016: musculoskeletal system and connective tissue diseases; circulatory system diseases; eye and its accessory apparatus diseases; respiratory organs diseases; digestive organs diseases. Their share is equal to $77.37 \%$ and $73.98 \%$ correspondingly. It is interesting to note a considerable frequency growth in such nosologic categories as ear and mastoid diseases represented by hearing loss (from 49.47 to 99.cases per 100 examined), skin and subcutaneous tissue diseases (from 7.73 to 36.3 cases per 100 examined), and urogenital system diseases (from 68.42 to 100.62 cases per 100 examined).

5. A great number of respondents pursue unhealthy life style: $72.8 \%$ of them smoke; $29.9 \%$, equally men and women, drink strong spirits; all the respondents tend to have insignificant physical activity.

6. There are some drawbacks in periodical medical examinations procedure: $26.3 \%$ respondents complained medical personnel were indifferent and even rude to them; $40.8 \%$ mentioned they had to wait for a doctor's receipt for a long time; 
$26.2 \%$ said they had to wait for a receipt in bad conditions; all the respondents said they didn't receive their health report on time.
The data we obtained can be applied in assessing health risks for workers employed at an enterprise and for developing prevention measures aimed at their minimization.

\section{References}

1. Barg A.O., Lebedeva-Nesevrya N.A. Risk-kommunikatsiya v sisteme analiza professional'nykh riskov zdorov'yu rabotnikov promyshlennogo predpriyatiya [Risk communication in analysis of occupational health risk for industrial workers]. Meditsinatruda i promyshlennayaekologiya, 2015, no. 8, pp. 28-33 (in Russian).

2. Zdorov'e rabotayushchikh: global'nyi plan deistvii (2008-2017 g.). Prinyat shestidesyatoi sessiei Vsemirnoi assamblei zdravookhraneniya 23.05.2007 g. [Workers' health: global plan of action (2008-2017.). Approved at the 60th session of the WHO on May 23, 2007]. Vsemirnaya organizatsiya zdravookhraneniya, Zheneva, 2007, pp.1-12. Available at: http://www.who.int/occupational_health/WHO_health_assembly_ru_web.pdf (03.09.2017) (in Russian).

3. Izmerov N.F. Aktualizatsiyavoprosovprofessional'noizabolevaemosti [Actualization of occupational morbidity issues]. Zdravookhranenie Rossiiskoi Federatsii, 2013, no.2, pp.14-17 (in Russian).

4. Izmerov N.F., Bukhtiyarov I.V., Prokopenko L.V. Voprosy professional'noi zabolevaemosti: retrospektiva i sovremennost' [Occupational morbidity issues: retrospect and contemporary situation]. Professiya i zdorov'e: Materialy XI Vserossiiskogo kongressa, Moskva, 27-29 noyabrya 2012 g. [Occupation and health: Materials of the XI Russian Congress, Moscow, November 27-29, 2012]. Moscow, FGBU «NII MT»RAMN, Publ., 2012, pp. 29-36 (in Russian).

5. MR 2.1.10.0033-11. Otsenka riska, svyazannogo s vozdeistviem faktorov obraza zhizni na zdorov'e naseleniya: Metodicheskie rekomendatsii / utv. Rospotrebnadzorom 31.07.2011 [Risk assessment related to the impact of lifestyle factors on human health: Methodical guidelines / approved by Rospotrebnadzor on July 31, 2011]. Available at: http://docs.cntd.ru/document/1200111974 (03.09.2017) (in Russian).

6. O sostoyaniisanitarno-epidemiologicheskogoblagopoluchiyanaseleniya v Permskom krae v 2015 godu: Gosudarstvennyi doklad [On sanitary-epidemiologic welfare of the population in Perm region in 2015: State report].Perm, Federal'naya sluzhba po nadzoru v sfere zashchity prav potrebitelei i blagopoluchiya cheloveka, Publ., 2016, 269 p. Available at: http://59.rospotrebnadzor.ru/c/document_library/get file?uuid=2e1fb575-f452-4f66-afee3255ed6e019c\&groupId=10156 (03.09.2017) (in Russian).

7. O sostoyanii sanitarno-epidemiologicheskogo blagopoluchiya naseleniya $\mathrm{v}$ Permskom krae v 2016 godu: Gosudarstvennyi doklad [On sanitary-epidemiologic welfare of the population in Perm region in 2016: State report]. Perm, Federal'naya sluzhba po nadzoru v sfere zashchity prav potrebitelei i blagopoluchiya cheloveka, Publ., 2017, 266 p. Available at: http://59.rospotrebnadzor.ru/c/document library/get file?uuid=1eb7862f-cd8a-4d9e-87dee687570fd5b8\&groupId=10156 (03.09.2017) (in Russian).

8. O sostoyanii sanitarno-epidemiologicheskogo blagopoluchiya naseleniya v Rossiiskoi Federatsii v 2015 godu: Gosudarstvennyi doklad [On sanitary-epidemiologic welfare of the population in the Russian Federation in 2015: State report]. Moscow, Federal'naya sluzhba po nadzoru v sfere zashchity prav potrebitelei i blagopoluchiya cheloveka, Publ., 2016, 200 p. Available at: http://docplayer.ru/28344531-Gosudarstvennyy-doklad-o-sostoyanii-sanitarno-epidemiologicheskogo-blagopoluchiya-naseleniya-v-rossiyskoy-federacii-v-2015-godu.html (03.09.2017) (in Russian). 
9. O sostoyanii sanitarno-epidemiologicheskogo blagopoluchiya naseleniya v Rossiiskoi Federatsii v 2016 godu: Gosudarstvennyi doklad [On sanitary-epidemiologic welfare of the population in the Russian Federation in 2016: State report]. Moscow, Federal'naya sluzhba po nadzoru v sfere zashchity prav potrebitelei i blagopoluchiya cheloveka, Publ., 2017, 216 p. Available at: http://rospotrebnadzor.ru/upload/iblock/0b3/gosudarstvennyy-doklad-2016.pdf (03.09.2017) (in Russian).

10. Onishchenko G.G. Sostoyanie uslovii truda i professional'naya zabolevaemost' rabotnikov $\mathrm{v}$ Rossiiskoi Federatsii [Working conditions and occupational morbidity in workers of the Russian Federation]. Gigiena i sanitariya, 2009, no. 3, pp. 66-70 (in Russian).

11. Professional'naya patologiya. Natsional'noe rukovodstvo [Occupational pathology. National guide]. In: N.F. Izmerov, ed. Moscow, GEOTAR-Media, Publ., 2012, 27 p. (in Russian).

12. Rakhmanin Yu.A., Sinitsyna O.O. Sostoyanie i aktualizatsiya zadach po sovershenstvovaniyu nauchno-metodologicheskikh i normativno-pravovykh osnov v oblasti ekologii cheloveka i gigieny okruzhayushchei sredy [Status and actualization of tasks to improve the scientific-methodological and regulatory frameworks in the field of human ecology and environmental hygiene]. Materialy Plenuma nauchnogo soveta po ekologii cheloveka i okruzhayushchei sredy Rossiiskoi Federatsii, Moskva, 1314 dekabrya $2012 \mathrm{~g}$. [Materials of the Scientific council plenary meeting on human ecology and environment in the Russian Federation, Moscow, December 13-14,2012]. Moscow, 2012, pp. 3-7 (in Russian).

13. Titov A.A., Titova E.Ya. O perspektivnykh napravleniyakh zheleznodorozhnoi meditsiny [Railway medicine prospects]. Problemy ekonomiki, organizatsii $i$ upravleniya $v$ Rossii $i$ mire: Materialy XY mezhdunarodnoi nauchno-prakticheskoi konferentsii [Issues of economics, organization and management in Russian and worldwide: Materials of the XY international theory and practical conference].Praga, 2017, pp. 65-68 (in Russian).

14. Titova E.Ya., Konovalova N.V. O nekotorykh aspektakh upravleniya zdorov'em personala [On certain aspects of managing personnel health]. Problemy ekonomiki, organizatsii i upravleniya $v$ Rossii i mire: Materialy YI mezhdunarodnoi nauchno-prakticheskoi konferentsii [Issues of economics, organization and management in Russian and worldwide: Materials of the YI international theory and practical conference]. Praga, 2014, pp. 224-225 (in Russian).

15. Khrupachev A.G., Khadartsev A.A., Kashintseva L.V., Sedova O.A Ekonomicheskie aspekty okhrany truda na osnove kolichestvennoi otsenki professional'nogo riska [Economic aspects of labor protection based on quantitative assessment of occupational risk]. Regional'naya ekonomika: teoriya i praktika, 2011, no. 19 (202), pp. 22-28 (in Russian).

16. Quality of the working environment and productivity: Research findings and case studies.Luxembourg, European Agency for Safety and Health at Work, 2004, 82 p. Available at: https://www.google.ru/url?sa=

t\&rct=j\&q=\&esrc $=$ s\&source=web\&cd=1\&ved=0ahUKEwjrq4_e24PYAhXEBZoKHajFBXM QFggoMAA\&url=

http\%3A\%2F\%2Fciteseerx.ist.psu.edu\%2Fviewdoc\%2Fdownload\%3Fdoi\%3D10.1.1.114.6196 \%26rep\%3Drep1\%26type\%3Dpdf\&usg=AOvVaw25cSJMKr2aqE4Xikt-1SOB (10.09.2017).

17. The Global Competitiveness Report 2010-2011. Geneva, World Economic Forum, $2010,516 \mathrm{p}$.

Titova E.Ya., Golub' S.A. Contemporary problems of health protection for workers employed at a large industrial enterprise and working under occupational hazards. Health Risk Analysis, 2017, no. 4, pp. 83-90. DOI: 10.21668/health.risk/2017.4.09.eng

Received: 12.09 .2017

Accepted: 22.12.2017

Published: 30.12.2017 